\title{
PENERAPAN KONSEP DIVERSI BAGI ANAK PENYANDANG DISABILITAS PELAKU TINDAK PIDANA KEKERASAN
}

\author{
Siti Komariah, Kayus Kayowuan Lewoleba \\ Fakultas Hukum Universitas Pembangunan Nasional Veteran Jakarta, Jakarta \\ sitikomariah@upnvj.ac.id
}

\begin{abstract}
Abstrak
Penelitian ini bertujuan untuk menganalisis perlindungan hukum terhadap anak penyandang disabilitas yang berhadapan dengan hukum menurut peraturan perundang-undangan di Indonesia serta penerapan konsep diversi bagi anak penyandang disabilitas pelaku tindak pidana kekerasan. Penelitian ini dilatarbelakangi oleh masih sedikitnya penelitian mengenai penerapan diversi pada anak penyandang disabilitas. Kebaharuan dari penelitian ini adalah belum adanya penelitian yang membahas mengenai penerapan diversi bagi anak penyandang disabilitas yang berhadapan dengan hukum sebagai pelaku tindak pidana kekerasan. Metode penelitian yang digunakan adalah yuridis-normatif dengan pendekatan perundang-undangan (statute approach) dan pendekatan konseptual (conseptual approach). Hasil penelitian menyimpulkan bahwa pertama, untuk kepentingan pemeriksaan proses hukum, anak penyandang disabilitas berhak mendapakan pendampingan dari keluarga atau pendamping yang bersangkutan. Kedua, konsep diversi dapat diterapkan untuk kasus kekerasan yang dilakukan anak penyandang disabilitas mulai dari tahap penyidikan, penuntutan, hingga proses peradilan di Pengadilan Negeri.
\end{abstract}

Kata Kunci: Anak Penyandang Disabilitas; Diversi; Perlindungan Hukum

\section{APPLICATION OF THE CONCEPT OF DIVERSION FOR CHILDREN WITH DISABILITIES OF VIOLENT CRIMINAL ACTS}

\begin{abstract}
This study aims to analyze the legal protection of children with disabilities who are in conflict with the law according to the laws and regulations in Indonesia and the application of the concept of diversion for children with disabilities who are perpetrators of violent crimes. This research is motivated by the lack of research on the application of diversion to children with disabilities. The novelty of this research is that there is no research that discusses the application of diversion for children with disabilities who are in conflict with the law as perpetrators of violent crimes. The research method used is juridical-normative with a statute approach and a conceptual approach. The results of the study conclude that first, for the purpose of examining the legal process, children with disabilities are entitled to assistance from the family or companion concerned. Second, the concept of diversion can be applied to cases of violence perpetrated by children with disabilities starting from the stage of imvestigation, prosecution, to the judicial process in the District Court.
\end{abstract}

Keywords: Children with Disabilities; Diversion; Legal Protection 


\section{A. PENDAHULUAN}

Anak merupakan individu yang unik sebagai harapan, penerus, dan pelurus bangsa. Anak memiliki hak-hak yang melekat pada dirinya sejak dilahirkan ke dunia, dengan didasarkan pada ketentuan yang berlaku. Hak-hak tersebut harus dipenuhi melalui kerjasama berbagai sektor demi masa depan bangsa yang lebih baik. Tidak terkecuali anak penyandang disabilitas, mereka juga memiliki hak-hak yang harus dipenuhi. Anak penyandang disabilitas dianggap memiliki kebutuhan yang khusus, seharusnya mereka mendapatkan perhatian yang lebih daripada anak-anak lainnya. Dalam keadaan tertentu, anak dengan disabilitas kerap melakukan hal-hal diluar perkiraan anak-anak lainnya dan secara aturan, perbuatan tersebut bisa termasuk tindak pidana. Anak dengan keterbatasan fisik, mental, maupun sensorik yang menyebabkan ketidakmampuan secara penuh untuk berpartisipasi dalam bermasyarakat yang selanjutnya dikenal dengan penyandang disabilitas ${ }^{1}$ sering menemukan banyak kendala dalam berkehidupan berbangsa dan bernegara. Perlindungan hukum pada anak dilaksanakan sebagai upaya untuk kebebasan dan hak asasi anak juga kepentingan yang berhubungan dengan kesejahteraan anak. ${ }^{2}$ Perlindungan hukum anak penyandang disabilitas merupakan sinergi dari berbagai elemen penegak hukum, berperan juga dokter spesialis kejiwaan. Hal ini penting tidak hanya bagi anak sebagai pelaku, tetapi juga anak sebagai korban dan anak sebagai saksi.

Seiring berkembangnya zaman, kasus kejahatan yang dilakukan oleh anak semakin meningkat, khususnya tindak pidana kekerasan. Hal ini dapat terjadi karena banyak faktor penyebab, seperti lingkungan pergaulan dan pola asuh keluarga yang salah. Setiap perbuatan yang dilakukan terhadap anak yang mengakibatkan penderitaan baik fisik, psikis, maupun seksual dapat diartikan sebagai tindakan kekerasan. ${ }^{3}$ Kemajuan teknologi dan industrialisasi memiliki korelasi dengan peningkatan kejahatan yang dilakukan oleh anak. Di masa sekarang, orang tua yang seharusnya menjadi contoh bagi anak-anaknya, justru lebih sibuk di luar yang menyebabkan perilaku anak kurang diperhatikan sehingga kejahatan oleh anak makin meningkat. Jika sudah terjadi, anak yang terlibat dalam kasus tindak pidana tidak memahami apa yang harus dilakukan. Ketika hak mereka dirampas begitu saja, mereka hanya bisa menuruti apapun yang dilakukan oleh orang dewasa kepadanya. Sebab, anak khususnya anak disabilitas merupakan kelompok yang paling rentan, mereka seringkali menjadi pihak yang paling dirugikan. ${ }^{4}$

\footnotetext{
${ }^{1}$ Republik Indonesia, “Undang-Undang Nomor 8 Tahun 2016 Tentang Penyandang Disabilitas” Pasal 1 angka 1 (2016).

${ }^{2}$ Waluyadi, "Hukum Perlindungan Anak" (Bandung: Mandar Maju, 2009), 1.

${ }^{3}$ Republik Indonesia, "Undang-Undang Nomor 35 Tahun 2014 Tentang Perubahan Atas Undang-Undang Nomor 23 Tahun 2002 Tentang Perlindungan Anak" Pasal 1 ayat 15a (2014).

${ }^{4}$ Arif Gosita, "Masalah Perlindungan Anak" (Jakarta: Sinar Grafika, 1992), 28.
} 
Anak penyandang disabilitas terkadang dimanfaatkan oleh orang-orang untuk melakukan suatu tindak pidana. ${ }^{5}$ Dalam penyelesaian kasus tindak pidana, anak penyandang disabilitas seharusnya mendapatkan hak-haknya untuk diperlakukan dengan baik oleh aparat penegak hukum berdasarkan prinsip kepentingan terbaik bagi anak (the best interest of the child). Namun, dalam pelaksanaannya, ketidakmampuan aparat penegak hukum dalam menangani kasus-kasus yang melibatkan anak penyandang disabilitas menjadi kendala pemenuhan hak-hak anak penyandang disabilitas. ${ }^{6}$ Selain itu, fakta di lapangan ditemukan bahwa masih kurangnya aksesibilitas bagi anak penyandang disabilitas pada intansi penegakkan hukum. Seharusnya, selain melalui pengaturan dalam perundang-undangan, pemerintah juga memenuhi aksesibilitas bagi para penyandang disabilitas di institusi penegakkan hukum. Hal ini dapat dipertegas dengan aturan tertulis yang diterbitkan pemerintah untuk institusi-institusi penegakkan hukum sehingga realisasinya dapat diawasi.

Indonesia telah memiliki payung hukum yang mengatur tentang proses peradilan pidana pada anak, khususnya anak sebagai pelaku. Anak sebagai pelaku disebut juga sebagai anak yang berkonflik dengan hukum, yaitu seorang anak yang umurnya telah mencapai 12 (dua belas) tahun tapi belum melebihi 18 (delapan belas) tahun dan diduga telah melakukan tindak pidana. ${ }^{7}$ UU 11/2012 tentang Sistem Peradilan Pidana Anak telah disahkan tanggal 30 Juli 2012 dan mulai efektif diberlakukan 2 (dua) tahun kemudian. Menurut UU 11/2012, dalam penyelesaian perkara pidana anak wajib diupayakan diversi. Diversi dilakukan dengan jalan musyawarah dan menerapkan konsep keadilan restoratif (restorative justice). Penjatuhan sanksi pidana penjara terhadap anak dinilai bukan solusi yang tepat untuk memberikan efek jera terhadap anak. Di dalam penjara, seorang anak tidak hanya sendiri, melainkan berkumpul dengan pelaku kejahatan lainnya yang dianggap akan memberikan pengaruh negatif terhadap anak. Oleh karena alasan tersebut, maka berbagai alternatif dipikirkan untuk kebaikan anak. Diversi dianggap sebagai upaya yang cukup efektif untuk menyelamatkan masa depan anak yang terlibat kasus tindak pidana. Dalam hal pelaksanaannya tidak selalu mencapai keberhasilan, kepentingan terbaik bagi anak harus tetap dikedepankan. Penghukuman anak dengan pidana penjara hanya dapat dilaksanakan sebagai upaya terakhir. ${ }^{8}$

Penelitian tentang konsep penerapan diversi dikaji oleh Raharjo (2017). Dalam tulisannya membahas tentang konsep diversi terhadap penyandag disabilitas yang menghasilkan bahwa konsep diversi terhadap anak penyandang disabilitas dapat dilakukan pada setiap proses peradilan sebagaimana peraturan perundang-undangan

${ }^{5}$ Trisno Raharjo and Laras Astuti, "Konsep Diversi Terhadap Anak Penyandang Disabilitas Sebagai Pelaku Tindak Pidana Dalam Sistem Peradilan Pidana Anak" 24, no. 2 (2017): 182, https://doi.org/10.18196/jmh.2017.0094.181-192.

${ }^{6}$ Henry Arianto, "Hak-Hak Bagi Para Penyandang Cacat (Disabilitas) Dalam Memperoleh Keadilan," (2017): 7.

${ }^{7}$ Republik Indonesia, "Undang-Undang Nomor 11 Tahun 2012 Tentang Sistem Peradilan Pidana Anak" Pasal 1 angka 3 (2012).

${ }^{8}$ Republik Indonesia, "Undang-Undang Nomor 39 Tahun 1999 Tentang Hak Asasi Manusia” Pasal 66 Ayat (4) (1999). 
yang berlaku. ${ }^{9}$ Penelitian lain tentang keadilan hukum bagi penyandang disabilitas dibahas oleh Priamsari (2019). Penelitian tersebut membahas tentang belum siapnya pemerintah dan aparat penegak hukum serta upaya dalam mewujudkan hukum yang berkeadilan bagi penyandang disabilitas. ${ }^{10}$ Penelitian mengenai penerapan diversi dalam penyelesaian perkara tindak pidana yang dilakukan anak juga dilakukan oleh Anzward (2020) yang membahas diversi dengan pendekatan keadilan restoratif. ${ }^{11}$

Penelitian ini dilakukan guna melengkapi penelitian-penelitian sebelumnya mengenai penerapan diversi pada anak pelaku tindak pidana. Pada penelitianpenelitian terdahulu, memiliki kesamaan yaitu sama-sama membahas tentang diversi serta keadilan hukum penyandang disabilitas. Penelitian ini memusatkan pembahasan pada penerapan konsep diversi terhadap anak penyandang disabilitas pelaku tindak pidana kekerasan yang berfokus pada kekerasan fisik, dengan mengaitkan antara UU 8/2016 tentang Penyandang Disabilitas dengan UU 11/2012 tentang Sistem Peradilan Pidana Anak. Tujuan dari penelitian ini adalah untuk mengetahui perlindungan hukum terhadap anak penyandang disabilitas yang berhadapan dengan hukum serta menganalisis penerapan konsep diversi bagi anak penyandang disabilitas pelaku tindak pidana kekerasan.

\section{B. PERMASALAHAN}

Berdasarkan penjabaran tersebut di atas, rumusan masalah penelitian ini yaitu: pertama, bagaimana perlindungan hukum terhadap anak penyandang disabilitas yang berhadapan dengan hukum? Kedua, bagaimana penerapan konsep diversi bagi anak penyandang disabilitas pelaku tindak pidana kekerasan di Indonesia?

\section{METODE PENELITIAN}

Penelitian ini menggunakan metode penelitian hukum normatif, yaitu dengan menguji data yang diperoleh dengan bertitik tolak pada aspek hukum (yuridis) melalui studi dokumen untuk mengkaji aspek-aspek internal dari hukum positif. Pendekatan yang digunakan dalam penelitian ini yaitu pendekatan perundang-undangan (statute approach) dan pendekatan konsep (conseptual approach). Teknik pengumpulan data yang digunakan adalah studi kepustakaan (library research) yaitu penelitian dilakukan dengan mengkaji bahan-bahan pustaka atau data sekunder. Analisis dalam penelitian ini berbentuk deskriptif kualitatif, yaitu penjabaran dengan kalimat-kalimat yang mudah dimengerti dan sistematis. Analisis ini digunakan untuk mengetahui penerapan konsep diversi bagi anak penyandang disabilitas pelaku tindak pidana kekerasan sesuai dengan peraturan perundang-undangan yang berlaku di Indonesia.

\footnotetext{
${ }^{9}$ Raharjo and Astuti, "Konsep Diversi Terhadap Anak Penyandang Disabilitas Sebagai Pelaku Tindak Pidana Dalam Sistem Peradilan Pidana Anak", 181-192.

${ }^{10}$ R R Putri A Priamsari, "Hukum Yang Berkeadilan Bagi Penyandang Disabilitas," Masalah-Masalah Hukum 48, no. 2 (2019): 215-223.

${ }^{11}$ Bruce Anzward and Suko Widodo, "Kebijakan Penerapan Diversi Dalam Penyelesaian Perkara Tindak Pidana Yang Dilakukan Oleh Anak Melalui Pendekatan Restorative Justice," Jurnal De Facto 7, no. 1 (2020): $38-59$.
} 


\section{HASIL DAN PEMBAHASAN}

\section{Perlindungan Hukum terhadap Anak Penyandang Disabilitas yang Berhadapan dengan Hukum}

Perlindungan hukum bagi anak penyandang disabilitas tidak bisa dilakukan sembarangan. Penanganannya harus serius oleh orang-orang yang berkompeten. Perlindungan hukum merupakan serangkaian proses, cara, dan upaya dalam aspek hukum yang wajib diberi oleh aparat penegak hukum guna memastikan rasa aman kepada seseorang, baik keamanan fisik maupun pikiran dari berbagai ancaman dan gangguan oleh siapapun. ${ }^{12}$ Anak penyandang disabilitas sering dianggap beban oleh masyarakat apalagi jika anak penyandang disabilitas harus berhadapan dengan hukum karena suatu hal yang diperbuatnya. Ini menjadikan label 'beban' oleh masyarakat terhadap si anak semakin menguat. Optimalisasi dalam perlindungan hukum terhadap penyandang disabilitas dapat dilakukan dengan upaya sinkronisasi antara peraturan perundang-undangan terkait penyandang disabilitas, agar terciptanya harmonisasi pada peraturan-peraturan tersebut. ${ }^{13}$ Penyandang disabilitas berhadapan dengan hukum yaitu seorang penyandang disabilitas yang memiliki konflik dalam aspek hukum, bisa sebagai pelaku, korban, maupun saksi. ${ }^{14}$ Perlindungan hukum terhadap anak penyandang disabilitas yang berhadapan dengan hukum yaitu sebagai berikut.

a. Undang-Undang No. 19 Tahun 2011 tentang Pengesahan Konvensi mengenai Hak-Hak Penyandang Disabilitas (Convention on the Rights of Persons with Disabilities)

Konvensi tentang Hak-Hak Penyandang Disabilitas telah diratifikasi Indonesia pada tanggal 10 November 2011 melalui Undang-Undang Nomor 19 Tahun 2011. Dengan diratifikasinya konvensi tersebut, para penyandang disabilitas diharapkan lebih diperhatikan oleh Negara melalui pemenuhan hak-haknya. Sehingga tidak menutup kemungkinan bagi anak penyandang disabilitas yang berkonflik dengan hukum turut mendapat perlindungan. Meski mereka bersalah, tapi mereka juga memiliki hak-hak yang harus dipenuhi. Pada Pasal 13 Konvensi tentan Hak-Hak Penyandang Disabilitas, terdapat ketentuan dlam aspek hukum yang mengatur hak dalam akses keadilan. Dalam konvensi ini, Negara memiliki tanggungjawab yaitu:

1) Negara mengakui bahwa penyandang disabilitas perempuan dan anak perempuan sangat rentan mengalami diskriminasi yang berlipat dan Negara wajib memenuhi hak asasi manusia secara utuh; ${ }^{15}$

\footnotetext{
${ }^{12}$ Ni Nyoman Muryantini and I Komang Setia Buana, "Perlindungan Hukum Terhadap Anak Penyandang Disabilitas Yang Ditelantarkan Oleh Orang Tuanya," Jurnal Advokasi 9, no. 1 (2019): 60.

${ }^{13}$ Ali Sodiqin, "Ambigiusitas Perlindungan Hukum Penyandang Disabilitas Dalam Perundang-Undangan Di Indonesia," Jurnal Legislasi Indonesia 18, no. 1 (2021): 33-34.

${ }^{14}$ Dio Anshar et al., Disabilitas Berhadapan Dengan Hukum Dalam Lingkup Pengadilan, ed. Theodora Y. S Putri and Muhammad Joni Yulianto (MaPPI FHUI \& AIPJ 2, 2019): 25.

${ }^{15}$ Republik Indonesia, “Undang-Undang Nomor 19 Tahun 2011 Tentang Pengesahan Convention on the Rights of Persons with Disabilities (Konvensi Mengenai Hak-Hak Penyandang Disabilitas)" Pasal 6 (2011).
} 
2) Negara wajib memastikan bahwa penyandang disabilitas memiliki hak diakui secara penuh di hadapan hukum serta memiliki kapasitas hukum yang sama dan Negara wajib mengambil langkah-langkah yang sesuai kapasitasnya; ${ }^{16}$

3) Negara wajib memberikan pelatihan peningkatan kapasitas bagi para pelaksana kebijakan dan aparat penegak hukum mengenai penanganan dan aksesibilitas penyandang disabilitas berhadapan dengan hukum; ${ }^{17}$

4) Negara wajib menjamin penyandang disabillitas bebas dari penyiksaan dan perlakuan tidak manusiawi serta wajib mengambil langkah tepat sebagai upaya pencegahan. ${ }^{18}$

b. Undang-Undang Nomor 18 Tahun 2014 tentang Kesehatan Jiwa

Kondisi kesehatan jiwa seseorang tidak dapat diketahui hanya dengan melihat orang tersebut secara sepintas dan divonis sendiri oleh orang awam. Untuk kepentingan penegakan hukum, bagi seseorang yang diduga dengan gangguan jiwa, harus dilakukan pemeriksaan kesehatan jiwa terlebih dahulu oleh ahli. Hal ini untuk memastikan kemampuan seseorang dalam bertanggungjawab secara hukum serta mengikuti proses peradilan. ${ }^{19}$ Ahli yang ditunjuk adalah dokter spesialis kejiwaan atau dokter spesialis lainnya. Lebih lanjut mengenai prosedur pelaksanaannya diatur dalam Permenkes 77/2015 tentang Pedoman Pemeriksaan Kesehatan Jiwa untuk Kepentingan Penegakkan Hukum. Ketentuan ini juga dapat diberlakukan bagi anak dengan disabilitas yang berhadapan dengan hukum.

c. Undang-Undang Nomor 8 Tahun 2016 tentang Penyandang Disabilitas Hadirnya UU 8/2016 tentang Penyandang Disabilitas memberikan angin segar terhadap pemenuhan hak-hak penyandang disabilitas. UU ini menggantikan UU sebelumnya yaitu UU 19/2011 tentang Penyandang Cacat yang dianggap diskiminatif terhadap penyandang disabilitas. Penyebutan penyandang cacat dirasa stigmatif sehingga membuat penyandang disabilitas tidak dianggap di masyarakat. UU 8/2016 mengatur secara lebih rinci mengenai hak penyandang disabilitas dan mengedepankan HAM, tidak terkecuali hak anak penyandang disabilitas yang berhadapan dengan hukum. Dalam UU 8/2016 diatur secara jelas mengenai perlindungan lebih khusus bagi perempuan dan anak penyandang disabilitas. ${ }^{20}$

Anak penyandang disabilitas berhak mendapatkan perlindungan yang khusus dari segala bentuk perlakuan tidak manusiawi dan kepentingannya harus dilindungi dalam setiap pengambilan keputusan. Dalam hal kepentingan pemeriksaan berkaitan dengan anak penyandang disabilitas yang berhadapan

\footnotetext{
${ }^{16}$ Indonesia, Pasal 12.

${ }^{17}$ Indonesia, Pasal 13.

${ }^{18}$ Indonesia, Pasal 15. (2014).

19 Republik Indonesia, "Undang-Undang Nomor 18 Tahun 2014 Tentang Kesehatan Jiwa" Pasal 71

${ }^{20}$ Indonesia, Undang-Undang Nomor 8 Tahun 2016 Tentang Penyandang Disabilitas, Pasal 126.
} 
dengan hukum, aparat penegak hukum harus mengizinkan keluarga atau pendamping anak untuk mendampingi dalam proses pemeriksaan anak penyandang disabilitas.

d. Undang-Undang Nomor 11 Tahun 2012 tentang Sistem Peradilan Pidana Anak

Indonesia memiliki hukum acara tersendiri bagi anak sebagai pelaku. Mengenai definisi anak sebagai pelaku, UU 11/2012 menyebut anak pelaku hanya dengan sebutan anak yang berkonflik dengan hukum yang kemudian sebutan ini dapat dipersamakan dengan anak sebagai pelaku untuk mempermudah pemahamannya. Dalam UU 11/2012 diamanatkan bahwa penyelesaian kasus anak yang berhadapan dengan hukum harus diusahakan dengan jalan diversi ${ }^{21}$ untuk mewujudkan keadilan restoratif. Secara sederhana, diversi diartikan sebagai penyelesaian perkara anak di luar proses peradilan pidana. UU 11/2012 memberikan perlindungan khusus terhadap anak yang berhadapan dengan hukum. Perlindungan khusus tersebut diwujudkan melalui pengupayaan diversi serta pengaturan mengenai hakhaknya.

Dalam melaksanakan proses peradilan, setiap anak dilindungi hakhaknya untuk mendapat perlakuan secara manusiawi, tidak bersama-sama orang dewasa dalam proses peradilan, mendaapatkan bantuan hukum, dirahasiakan identitasnya, serta untuk anak penyandang disabilitas berhak mendapatkan aksesibilitas yang memadai, selain itu terdapat hak-hak lain yang diatur sesuai ketentuan perundang-undangan. Berkaitan dengan proses peradilan pidana anak, tetap dilakukan serangkaian tahapan seperti penangkapan, penahanan, serta peradilan. Namun proses-proses tersebut dilaksanakan dengan cara-cara yang lebih ramah anak. Pelaksanaan sistem peradilan anak tidak terlepas dari aparat penegak hukum, oleh karenanya diperlukan aparat penegak hukum yang memahami kepentingan anak. Terlebih jika anak yang berhadapan dengan hukum tersebut merupakan anak penyandang disabilitas. Sangat diperlukan kemampuan dan pemahaman terkait penanganan yang tepat untuk anak disabilitas yang berhadapan dengan hukum.

\section{Penerapan Konsep Diversi bagi Anak Penyandang Disabilitas Pelaku Tindak Pidana Kekerasan di Indonesia}

Hak asasi anak merupakan bagian dari hak asasi manusia. Pemenuhan hak-hak anak adalah perwujudan dari pemenuhan hak asasi manusia. Anak adalah generasi penerus bangsa, tidak terkecuali anak penyandang disabilitas. Disabilitas yang dialami oleh seseorang memiliki berbagai ragam, yaitu: a) Disabilitas fisik, ialah fungsi gerak tubuh yang terganggu; b) Disabilitas intelektual, adalah tingkat kecerdasan seseorang yang di bawah rata-rata orang pada umumnya; c) Disabilitas

\footnotetext{
${ }^{21}$ Indonesia, Undang-Undang Nomor 11 Tahun 2012 Tentang Sistem Peradilan Pidana Anak, Pasal 7.
} 
mental yaitu fungsi pikir, emosi, serta perilaku seseorang yang terganggu; c) Disabilitas sensorik, yaitu salah satu fungsi panca indera yang terganggu; d) Disabilitas ganda/multi yaitu dua atau lebih jenis disabilitas yang dimiliki oleh seseorang.

Seharusnya setiap anak mendapat pemenuhan hak yang sama. Namun, sulit bagi masyarakat untuk bisa menghargai hak-hak anak penyandang disabilitas. Bahkan tidak jarang, anak penyandang disabilitas dimanfaatkan demi kepentingan pribadi. Anak penyandang disabilitas kerap diperintah oleh orang yng tidak bertanggungjawab untuk berbuat sesuatu yang termasuk ke dalam tindak pidana. Salah satunya demi kepentingan balas dendam, anak penyandang disabilitas diminta untuk melakukan pemukulan terhadap anak lainnya. Bisa saja, anak penyandang disabilitas tersebut tidak hanya melakukan pemukulan, melainkan perbuatan lain yang termasuk ke dalam tindak pidana kekerasan dan bisa memperparah kondisi korban. Dalam hal ini, anak penyandang disabilitas tidak menyadari bahkan tidak mengetahui yang telah dilakukannya bisa menyeret dirinya ke ranah hukum. Dengan demikian, lingkungan sosial turut andil dalam perlindungan anak, selain peran keluarga yng menanamkan nilai-nilai moral dalam kehidupan. ${ }^{22}$ Lingkungan sosial yang membawa efek negatif pada anak, dapat membuat anak menjadi pribadi yang rentan melakukan kejahatan.

Menjadi orang dewasa mungkin memang sulit, namun menjadi seorang anak tidaklah mudah ketika dihadapkan pada sesuatu yang harus anak lakukan, tpi anak tidak mengetahui tujuannya. Terlebih bagi anak pnyandang disabilitas yang memrlukan bimbingan khusus dalam kegiatan sehari-hari. Tanggapan umum oleh Mahogany Weight menyatakan bahwa orang-orang penyandang disabilitas sebagai pelaku sering dilabeli bahwa mereka mengalami kesulitan untuk mengungkapkan fakta dan sering kebingungan mengenai orang yang harus mempertanggungjawabkan suatu kejahatan atau ia merasa harus mengaku atas apa yang tidak dilakukannya. ${ }^{23}$

Sebagai warga negara, anak penyandang disabilitas memiliki hak dan kewajiban yang sama dengan warga negara lainnya. Begitupun ketika anak disabilitas diduga melakukan tindak pidana. Anak-anak yang telah melakukan suatu tindak pidana tidak diperlakukan sama seperti orang dewasa. Hal ini dikarenakan adanya sistem hukum acara tersendiri yang berlaku untuk anak-anak. ${ }^{24}$ Hukum pidana Indonesia mengatur tentang anak yang berhadapan dengan hukum harus tetap diproses sesuai dengan aturan yang berlaku yaitu sistem peradilan pidana anak di Indonesia sebagai bentuk pertanggungjawaban terhadap negara. Pertanggungjawaban terhadap negara oleh anak yang berhadapan dengan hukum

\footnotetext{
${ }^{22}$ Ni Ketut Ayu Suwandewi and Ni Nengah Adiyaryani, "Diversi Sebagai Bentuk Perlindungan Anak Dalam Sistem Peradilan Di Indonesia," Kertha Patrika 42, no. 3 (2020): 277.

${ }^{23}$ Supriyadi Widodo Eddyono and Ajeng Gandini Kamilah, Aspek - Aspek Criminal Justice Bagi Penyandang Disabilitas, ed. Widiyanto (Institute for Criminal Justice Reform, 2015): 9.

${ }^{24}$ Muhammad Rizal Lampatta and Irham Yasir, "Perlindungan Hukum Terhadap Tersangka Anak Dalam Proses Penyidikan Di Kepolisian Resor Pohuwato" 2, no. 1 (2020): 61.
} 
dilakukan melalui aparat penegak hukum. ${ }^{25}$ Sistem Peradilan Pidana Anak yaitu serangkaian proses dalam penyelesaian perkara anak yang berhadapan dengan hukum mulai dari tahap penyelidikan hinggaa tahap pembimbingan setelah anak melakukan masa pidana. ${ }^{26}$ Penyandang disabilitas termasuk subyek hukum dan harus tetap dimintakan pertanggungjawaban hukum. Namun, dalam prosesnya harus melalui berbagai prosedur khusus. Sama seperti anak-anak lainnya, anak penyandang disabilitas juga memiliki masa depan yang masih panjang. Untuk kebaikan kelangsungan hidupnya, sistem peradilan pidana anak mengedepankan upaya diversi bagi anak yang berkonflik dengan hukum. Diversi dilakukan dengan didasarkan pada keadilan restoratif (restorative justice), yaitu penekanan pada pemulihan keaadaan seperti saat semula belum terjadi tindak pidana, bukan merupakan pembalasan. Diversi berperan penting dalam memberikan perlindungann terhadap hak-hak asasi anak. ${ }^{27}$ Meskipun UU 11/2012 mengamanatkan upaya diversi terhadap perkara anak, tetapi tidak semua perkara anak dapat diselesaikan dengan diversi. Hanya perkaraperkara yang ancaman pidananya adalah pidana penjara dibawah 7 (tujuh) tahun dan bukan merupakan pengulangan tindak pidana yang harus diupayakan diversi. Jalan diversi dirasa sebagai alternatif terbaik untuk penyelesaian perkara yang melibatkan anak penyandang disabilitas, karena dalam proses diversi, rasa keadilan sangat diprioritaskan serta menghargai prinsip kepentingan terbaik bgi anak. Ini sejalan dengan beberapa prinsip yang melekat pada penerapan diversi, yaitu: ${ }^{28}$

a. Diversi ditujukan agar terciptanya suasana damai antara si pelaku dan si korban dengan berbagai alternatif seperti penggantian kerugian atau permohonan maaf sehingga dianggap tidak ada permasalahan lagi, juga penyesalan dari pelaku untuk tidak mengulangi hal yang telah diperbuatnya.

b. Program dalam diversi dapat berbentuk pemberian peringatan kepada pelaku, pelaku dibina keterampilannya, maupun pelaksanaan pembimbingan atau konseling kepada pelaku.

c. Kasus-kasus yang ditemukan penyelesaiannya dengan diversi biasanya adalah kasus yang tergolong tidak berat serta tidak menimbulkan bahaya bagi masyarakat juga kaarena adanya kedekatan antara si pelaku dengan si korban.

Diversi pada dasarnya berbentuk musyawarah mufakat untuk menengahi konflik yang terjadi antara pelaku dengan korban dan diharapkan kepentingan kedua belah pihak dapat terpenuhi, dimana korban tergantikan kerugiannya dan pelaku terselamatkan masa depannya karena terhindar dari proses hukum di pengadilan maupun pemenjaraan. Ketika proses diversi mencapai kesepakatan, harus dipastikan bahwa seorang anak tidak boleh merasa dirinya tertekan oleh keadaan atau ditekan

${ }^{25}$ Zulfikar Judge, "Kedudukan Anak Yang Berhadapan Dengan Hukum Selaku Pelaku Tindak Pidana (Studi Kasus : 123/PID.SUS/2014/PN.JKT.TIM),” Lex Jurnalica 13, no. 1 (2016): 53. angka 1 .

${ }^{26}$ Indonesia, Undang-Undang Nomor 11 Tahun 2012 Tentang Sistem Peradilan Pidana Anak, Pasal 1

${ }^{27}$ Beniharmoni Harefa, "Diversi Sebagai Perlindungan Hukum Terhadap Hak Asasi Anak Dalam Sistem Peradilan Pidana Anak Di Indonesia,” Jurnal Komunikasi Hukum 1, no. 1 (2015): 4.

${ }^{28}$ Ratomi, "Konsep Prosedur Pelaksanaan Diversi Pada Tahap Penyidikan Dalam Penyelesaian Tindak Pidana Yang Dilakukan Oleh Anak", 401. 
untuk menyetujui hasil diversi. ${ }^{29}$ Diversi memiliki sifat ultimum remedium, yang dapat diartikan bahwa pemidanaan bagi anak adalah upaya hukum yang paling terakhir jika tidak ada upaya-upaya hukum lain yang bisa dilakukan dan dapat menguntungkan anak. ${ }^{30}$ Anak penyandang disabilitas yang berkonflik dengan hukum bisa saja terjadi. Banyak faktor yang menyebabkan anak-anak disabilitas bisa melakukan tindak pidana misalnya seperti anak penyandang disabilitas seringkali tidak dapat mencerna dengan jelas dalam pikirannya, mana hal yang baik dan mana hal yang buruk; Ketidaktahuan anak penyandang disabilitas atas apa yang mereka perbuat bisa termasuk ke dalam tindak pidana; Keinginan besar anak penyandang disabilitas untuk diakui di lingkungannya dan memiliki teman-teman sepermainan sehingga terpaksa menuruti permintaan temannya untuk melakukan hal yang bisa temasuk ke dalalm tindak kejahatan; Ketidakberdayaan anak penyandang disabilitas untuk melawan atau menolak hal-hal yang tidak sesuai dengan nurani hatinya; serta anak penyandang disabilitas cenderung tidak dapat mengekspresikan apa yang dialaminya dengan baik, seperti perasaan terpaksa kepada orang tua/walinya, sehingga keluarga terdekatnya tidak mengetahui apa yang sudah ia lakukan.

Ketika seorang anak penyandang disabilitas telah melakukan perbuatan tindak pidana kekerasan, maka ia harus tetap mempertanggungjawabkan perbuatannya secara hukum sesuai dengan sistem peradilan pidana anak. Hingga saat ini, belum ada aturan khusus yang mengatur tentang anak penyandang disabilitas yang berhadapan dengan hukum sebagai pelaku tindak pidana. Namun, Indonesia telah memiliki aturan-aturan terkait hal tersebut. Secara umum, prosedurnya sebagai berikut:

a. Sebelum dilakukan pemeriksaan oleh aparrat penegak hukum, penyandang disabilitas mental/ODGJ yang diduga melakukan tindak pidana, wajib dilakukan pemeriksaan kesehatan jiwa untuk kepentingan penegakan hukum. ${ }^{31}$

Pemeriksaan kejiwaan bagi penyandang disabilitas dengan ganggun jiwa bertujuan untuk menentukan sejauh mana kemampuannya untuk mempertanggungjawabkan perbuatannya. Pemeriksaan ini dapat dilakukan di rumah sakit umum pemerintah maupun daerah yang hasilnya akan disusun oleh dokter spesialis kejiwaan yang bersangkutan dalam bentuk Visum et Repertum Psychiatricum (VeRP). ${ }^{32}$ VeRP tersebut harus diserahkan oleh pihak rumah sakit ke pengadilan atau instansi pemohon dalam kurun waktu paling lambat 7 (tujuh) hari sejak selesainya pemeriksaan kesehatan jiwa.

108.

${ }^{29}$ Fetri A. R Tarigan, “Upaya Diversi Bagi Anak Dalam Proses Peradilan,” Lex Crimen IV, no. 5 (2015):

${ }^{30}$ Ricky Martin Sihombing, M Hamdan, and Marlina, "Perlindungan Hukum Terhadap Anak Sebagai Pelaku Tindak Pidana Kekerasan (Analisis Putusan No. 9/PID.SUS-ANAK/2018/PN TJB)," Jurnal Mahupiki 1, no. 9 (2019): 17.

${ }^{31}$ Indonesia, Undang-Undang Nomor 18 Tahun 2014 Tentang Kesehatan Jiwa, Pasal 71.

${ }^{32}$ Anshar et al., Disabilitas Berhadapan Dengan Hukum Dalam Lingkup Pengadilan, 30. 
b. Bagi perempuan dan anak penyandang disabilitas berhak mendapatkan perlindungan lebih khusus dari pemerintah pusat maupun daerah sesuai dengan ketentuan peraturan perundang-undangan. ${ }^{33}$

Perlindungan khusus bagi perempuan dan anak penyandang disabilitas bisa bermacam bentuk, seperti misalnya layanan rehabilitasi, pendampingan atau konseling, serta rumah aman yang ramah disabilitas. Bagi anak penyandang disabilitas yang berkonflik dengan hukum, wajib dilakukan pendampingan dalam proses penyelesaian perkara hukumnya serta tidak ada perlakuan tidak manusiawi.

c. Penyandang disabilitas berhak mendapatkan pelayanan publik yang ramah disabilitas

Tidak bisa dipungkiri bahwa penyandang disabilitas memerlukan bantuan dalam beraktivitas di ruang publik. Anak penyandang disabilitas yang berhadapan dengan hukum berhak mendapatkan aksesibilitas yang memadai pada pelayanan publik termassuk di pengadilan atau institusi penegakkan hukum lainnya. Hak mendapatkan pelayanan publik yang memadai bagi anak penyandang disabilitas misalnya seperti mendapat akomodasi layak untuk dirinya dan keluarganya, memperoleh pendampingan, serta fasilitas yang mudah di akses tanpa biaya.

Dalam hal pemenuhan hak-hak anak penyandang disabilitas berhadapan dengan hukum, penting bagi keluarga mengetahui prosedur pelaksanaannya serta sangat penting bagi aaparat penegak hukum untuk memahami cara-cara terbaik untuk menangani kasus yang melibatkan anak penyandang disabilitas. Kerumitan dan masih belum jelasnya kepastian hukum mengenai prosedur penanganan terhadap anak penyandang disabilitass yang berhadapan dengan hukum, menjadikan konsep diversi harus dikedepankan. Ini sejalan dengan asas utama konstitusi negara dalam hal perlindungan hukum terhadap anak di Indonesia jika dilihat dalam aspek perundang-undangan yaitu asas kepentingan terbaik bagi anak. ${ }^{34}$ Selain bertujuan untuk menyelamatkan masa dpean anak, secara spesifik diversi memiliki tujuan untuk menciptakan rasa perdamaian diatara korban dan pelaku, penghindaran kemerdekaan anak yang dirampas, serta penananman taanggung jawab pada anak.

Pihak-pihak yang terlibat dalam proses musyawarah dalam upaya diversi yaitu anak itu sendiri dan orang tua/walinya, korban dan/atau bersama orang tua/walinya, pembimbing kemasyarakatan, serta pekerja sosial profesional yang pelaksanaannya didasarkan pada keadilan restoratif. Dapat juga dilibatkan masyarakat dalam pelaksanaan proses diversi jika diperlukan. Terdapat beberapa hal yang wajib diperhatikan dalam proses diversi, yaitu kepentinga si korban, kesejaahteraan dan rasa tanggungjawab anak, anak harus dihindarkan dari stigma buruk, harus

${ }^{33}$ Indonesia, Undang-Undang Nomor 8 Tahun 2016 Tentang Penyandang Disabilitas, Pasal 126.

${ }^{34}$ Dheny Wahyudhi and Sri Rahayu, "Pemenuhan Hak-Hak Anak Yang Berkonflik Dengan Hukum Melalui Proses Diversi Dalam Peradilan Anak," in Prosiding Seminar Hukum Dan Publikasi Nasional (Serumpun), 2019, 76. 
diperhatikan juga anak terhindar dari tindakan pembalasan, menjaga keharmonisan di lingkungan masyarakat, serta norma-norma sosial seperti kepatutan juga ketertiban umum. Dalam pelaksanaan proses diversi, aparat penegak hukum harus mempertimbangkan beberapa hal, yaitu kategori tindak pidana yang dilakukan anak, usia anak, hasil penelitian kemasyarakatan yang telah dilakukan oleh Bapas, serta adanya dukungan dari keluarga dan lingkungan masyarakat. Dalam hal melaksanakan proses diversi yang menangani perkara anak, aparat penegak hukum yang ditugaskan adalah aparat penegak hukum khusus anak yang setidaknya pernah mengikuti pelatihan tentang prosedur menangani perkara-perkara anak atau memiliki ketertarikan dengan isu-isu anak. Jika tidak ada, aparat penegak hukum yang bertugas tetap yang biasa menagani perkara orang dewasa tetap dengan memperhatikan ketentuan yang berlaku.

Tabel 1. Proses Pelaksanaan Diversi

\begin{tabular}{|c|c|c|c|c|}
\hline Tahapan & $\begin{array}{c}\text { Jangka } \\
\text { Waktu }\end{array}$ & $\begin{array}{c}\text { Lama } \\
\text { Pelaksanaan }\end{array}$ & Pelaksana & Tindak Lanjut \\
\hline Penyidikan & $\begin{array}{l}7 \text { (tujuh) hari } \\
\text { sejak dimulai } \\
\text { penyidikan }\end{array}$ & $\begin{array}{l}\text { Paling lama } \\
30 \text { (tiga } \\
\text { puluh) hari }\end{array}$ & $\begin{array}{c}\text { Penyidik } \\
\text { Anak }\end{array}$ & $\begin{array}{l}\text { Berhasil: berita } \\
\text { acara hasil } \\
\text { diversi } \\
\text { Tidak Berhasil: } \\
\text { pelimpahan } \\
\text { perkara ke } \\
\text { Penuntut } \\
\text { Umum } \\
\end{array}$ \\
\hline Penuntutan & $\begin{array}{l}7 \text { (tujuh) hari } \\
\text { setelah } \\
\text { menerima } \\
\text { berkas } \\
\text { perkara dari } \\
\text { Penyidik }\end{array}$ & $\begin{array}{l}\text { Paling lama } \\
30 \text { (tiga } \\
\text { puluh) hari }\end{array}$ & $\begin{array}{c}\text { Penuntut } \\
\text { Umum } \\
\text { Anak }\end{array}$ & $\begin{array}{l}\text { Berhasil: berita } \\
\text { acara hasil } \\
\text { diversi } \\
\text { Tidak Berhasil: } \\
\text { pelimpahan } \\
\text { perkara ke } \\
\text { Pengadilan }\end{array}$ \\
\hline Peradilan & $\begin{array}{l}7 \text { (tujuh) hari } \\
\text { setelah } \\
\text { Hakim } \\
\text { ditetapkan } \\
\text { oleh Ketua } \\
\text { Pengadilan } \\
\text { Negeri }\end{array}$ & $\begin{array}{l}\text { Paling lama } \\
30 \text { (tiga } \\
\text { puluh) hari }\end{array}$ & $\begin{array}{l}\text { Hakim } \\
\text { Anak }\end{array}$ & $\begin{array}{l}\text { Berhasil: berita } \\
\text { acara hasil } \\
\text { diversi } \\
\text { Tidak Berhasil: } \\
\text { proses } \\
\text { persidangan }\end{array}$ \\
\hline
\end{tabular}

Sumber: Diolah dari Data Penelitian, 2021

Berdasarkan Tabel 1, diversi wajib dilaksanakan oleh penyidik terhadap anak yang berhadapan dengan hukum dalam jangka waktu paling lama 7 (tujuh) hari sejak dimulainya penyidikan ditandai dengan adanya Surat Pemberitahuan Dimulainya Penyidikan (SPDP) yang dikirim oleh penyidik ke kejaksaan negeri setempat. Kemudian proses diversi dilaksanakan dalam waktu paling lama 30 (tiga puluh) hari. 
Apabila diversi yang dilakukan telah berhasil, penyiidik wajib membuat berita acara hasil diversi yang berisi kesepakatan hasil diversi dan ditujukan kepada ketua pengadilan negeri setempat untuk dibuatkan penetapan. Jika diversi tidak menemukan titik terang, maka penyidik akan melanjutkan penyidikan dan perkara dilimpahkan ke penuntut umum beserta lampiran berita acara dan laporan penelitian oleh masyarakat. Kemudian dalam tahap penuntutan, penuntut umum juga wajib melakukan diversi, walaupun kegagalan diversi telah terjadi pada tahap penyidikan. Ketentuan diversi pada tahap penuntutan menggunakan cara-cara yang sama seperti pada saat tahap penyidikan.

Diversi yang berhasil, maka wajib juga bagi penuntut umum untuk membuat berita acara hasil diversi serta menyerahkannya kepada ketua pengadilan negeri setempat untuk diterbitkan penetapan. Namun, ketika diversi kembali menemukan kegagalan, penuntut umum akan melimpahkan perkara tersebut ke pengadilan negeri setempat beserta berkas-berkas hasil diversi. Di pengadilan negeri, hakim juga wajib mengupayakan diversi. Ketentuan-ketentuan yang sama diterapkan dalam proses diversi di pengadilan seperti pada saat tahap penyidikan dan penuntutan. Bilamana diversi mencapai kesepakatan, hakim akan membuat berita acara hasil diversi ditujukn kepada ketua pengadilan negeri.

Diversi yang berhasil mencapai kesepakatan, hasil kesepakatannya dapat berbentuk penggantian kerugian kepada korban untuk tujuan perdamaian atau perdamaian dapat dilakukan tanpa penggantian kerugian, anak pelaku dikembalikan kepada orang tua/walinya, anak pelaku diikutsertakan dalam kegiatan pendidikan atau pelatihan dengan jangka waktu paling lama 3 (tiga) bulan, atau dilakukan pelayanan masyarakat. Jika terjadi kegagalan kembali pada proses diversi di tingkat pengadilan, maka perkara tersebut akan berlanjut ke tahap persidaangan. Dalam pelaksanaan persidangan anak di pengadilan negeri, seluruh pihak yang terlibat seperti hakim, penuntut umum, dan penasehat hukum, tidak menggunakan pakaian formal seperti pada persidangan orang dewasa. Seluruh atribut formal persidangan dilepas dan diganti dengan pakaian sehari-hari. Hal ini dilakukan untuk menghindarkan anak dari perasaan diskriminatif dan ketakutan dalam mengikuti proses persidangan.

Dalam hal berkaitan dengan anak dengan dugaan disabilitas mental yang berhadapan dengan hukum sebagai pelaku tindak pidana kekerasan, ada kemungkinan besar anak tersebut tidak dikenakan pidana atau terlepas dari hukuman pidana dengan pertimbangan hakim yang didukung hasil pemeriksaan kesehatan jiwa anak yang bersangkutan. Ketika di dalam hasil pemeriksaan kesehatan jiwa, anak dinyatakan tidak bisa melakukan tanggungjawab hukumnya, maka anak tersebut bisa dibebaskan dari tuntutan pidana. Pertimbangan hasil kesehatan jiwa yang dimaksud yaitu anak penyandang disabilitas mental tersebut menurut undang-undang tidak dapat mempertanggungjawabkan perbuatannya dikarenakan keadaan jiwanya yang 
cacat dalam pertumubuhan atau karena penyakit, maka ia tidak dapat dipidana. Kemudian jika dikarenakan anak pelaku tersebut tidak dapat mempertanggungjawabkan apa yang telah ia perbuat, atas perintah hakim, ia dapat dimasukkan ke rumah sakit jiwa dalam jangka waktu paling lama 1 (satu) tahun sebagai masa percobaan. ${ }^{35}$

Dalam kaitannya dengan anak penyandang disabilitas pelaku tindak pidana kekerasan, sebelumnya perlu diketahui bahwa tindak pidana kekerasan fisik dipersamakan dengan penganiayaan karena penganiayaan dipersamakan dengan kesengajaan merusak kesehatan orang yang diatur dalam Pasal 351 Kitab Undangundang Hukum Pidana dengan ancaman pidana penjara maksimal 2 (dua) tahun 8 (delapan) bulan penjara. Jika terdapat luka berat akibat penganiayaan tersebut, pelaku dapat dipidana penjara maksimal 5 (lima) tahun. Kemudian jika terdapat korban kematian akibat perbuatan penganiayaan tersebut, maka ancaman pidananya menjadi maksimal 7 (tujuh) tahun penjara. Maka, sejauh perbuatan penganiayaan yang dilakukan tidak mengakibatkan kematian pada korban, anak pelaku harus diupayakan diversi sebab ancaman pidananya masih dibawah 7 (tujuh) tahun penjara.

Bilamana tindak pidana kekerasan fisik yang dilakukan oleh anak penyandang disabilitas terhadap anak korban, makaa menurut UU 35/2014 tentang Perlindungan Anak, pelaku dapat dijerat dengan Pasal 80 jo. Pasal 76C UU 35/2014 dengan ancaman pidana penjara maksimal 3 (tiga) tahun 6 (enam) bulan. Apabila perbuatan tersebut menimbulkan luka berat pada anak korban, maka pelaku dapat dipidana penjara maksimal 5 (lima) tahun. Selanjutnya jika perbuatan tersebut menyebabkan kematian pada anak korban, pelaku diancam pidana penjara paling lama 15 (lima belas) tahun. Pemidanaan bagi pelaku yang oleh karena perbuatannya menimbulkan korban anak terasa lebih berat dibandingkan dengan aturan hukum yang dikenakan kepada pelaku yang korbannya orang dewasa. Sebaliknya, jika pelaku yang melakukan tindak pidana adalah anak, undang-undang meringankan hukuman pidananya karena hak-hak anak harus tetap dijunjung tinggi dan dilindungi. ${ }^{36} \mathrm{Hal}$ ini karena anak-anak memiliki pengaturan sendiri yang melindungi hak-haknya terutama dalam hal tindak pidana kekerasan yang menjadikan anak sebagai korban bahwa siapapun tidak boleh menempatkan, membiarkan, melakukan, menyuruh melakukan, atau turut serta terlibat dalam tindak pidana kekerasan terhadap anak.

Meskipun belum secara spesifik ada peraturan perundang-undangan yang mengatur berkaitan dengan anak penyandang disabilitas yang berhadapan dengan hukum sebagai pelaku tindak pidana kekerasan, setidaknya peraturan-peraturan terkait yang sudah ada, dapat mengatur proses hukum yang harus dilalui oleh anak penyandang disabilitas pelaku tindak pidana kekerasan. Walaupun aturan-aturan tersebut sudah ada sejak lama, tapi dalam pelaksanaannya masih belum optimal dan

\footnotetext{
${ }^{35}$ Republik Indonesia, "Kitab Undang-Undang Hukum Pidana” Pasal 44.

36 Theresia Adelina and A. A. Ngurah Yusa Darmadi, "Perlindungan Hukum Terhadap Anak Sebagai Pelaku Tindak Pidana Penganiayaan (Di Wilayah Hukum Kepolisian Resor Kota Denpasar)," Kertha Wicara: Journal Ilmu Hukum 7, no. 5 (2017): 6.
} 
tidak jarang menemukan hambatan-hambatan baik internal maupun eksternal. Terkhusus bagi anak penyandang disabilitas, untuk mendapatkan keadilan bukan merupakan suatu hal yang mudah. Beberapa hambatan yang ditemukan yaitu:

a. Hambatan internal

1) Disabilitas itu sendiri

Anak penyandang disabilitas sulit menentukan mana hal yang benar dan salah. Anak disabilitas sering tidak berani untuk bercerita kepada keluarga atas apa yang telah dilakukannya. Keterbatasan gerak yang dialami oleh penyandang disabilitas juga menghambat penyandang disabilitas untuk bisa menghindar dari hal yang tidak diinginkannya. Diperlukan karakter inklusif dalam diri seorang penyandang disabilitas untuk menjadi mandiri, ${ }^{37}$ yaitu berpartisipasi aktif dalam perlindungan dan pemenuhan hak-hak dirinya sendiri.

2) Keluarga

Tidak sedikit keluarga yang merasa bahwa memiliki anggota keluarga dengan disabilitas adalah sebuah aib yang harus ditutupi. Keluarga yang menerapkan pola asuh salah terhadap anak penyandang disabilitas dapat menjadikan anak terjerumus ke dalam kejahatan. Oleh karenanya peran keluarga sangat penting dalam proses tumbuh kembang anak penyandang disabilitas, sebab keluarga yang seharusnya melindungi anak dari bahaya, ${ }^{38}$ termasuk melindungi anak agar tidak melakukan tindakan yang dapat membahayakan orang lain maupun dirinya sendiri.

b. Hambatan eksternal

1) Keterbatasan informasi

Informasi pelayanan hukum bagi anak penyandang disabilits yang berhadapan dengan hukum masih cukup minim. Padahal penting untuk merka/keluarganya mendapat informasi tersebut jika harus dihadapkan pada proses hukum.

2) Aparat penegak hukum yang belum paham kebutuhan penyandang disabilitas

Hal ini menjadi yang paling krusial, karena aparat penegak hukum adalah orang-orang yang bersentuhan langsung dengan penyandang disabilitas yang berhadapan dengan hukum. Diperlukan pelatihan bagi para aparat penegak hukum terkait penanganan anak disabilitas yang berhadapan dengan hukum.

3) Aksesibilitas bagi penyandang disabilitas

\footnotetext{
${ }^{37}$ Katherine Elisabeth Jones, Shelly Ben-david, and Rachelle Hole, "Are Individuals with Intellectual and Developmental Disabilities Included in Research? A Review of the Literature," Research and Practice in Intellectual and Developmental Disabilities, 2019, 1-21, https://doi.org/10.1080/23297018.2019.1627571.

${ }^{38}$ Fred Wulczyn, Arno Parolini, and Scott Huhr, "Human Capital and Child Protection : A Research Framework in the CRC Context," Child Abuse \& Neglect 119 (2021): 2, https://doi.org/10.1016/j.chiabu.2020.104610.
} 


\section{E. PENUTUP}

Aksesibilitas bagi penyandang disabilitas di institusi penegakkan hukum masih kurang. Hal ini membuat keterbatasan penyandang disabilitas makin terasa, karena tidak didukung pemenuhan hak-haknya.

4) Lingkungan masyarakat

Anak disabilitas dicap beban masyarakat sehingga keberadaannya sering tidak diakui. Anak disabilitas yang melakukan tindak pidana, tanpa memikirkan konsekuensinya, masyarakat tidak jarang menghukum anak tersebut dengan cara main hakim sendiri bukan dengan cara-cara sesuai undang-undang.

Perlindungan hukum terhadap anak penyandang disabilitas di Indonesia diatur dalam beberapa peraturan perundang-undangan, yaitu UU 19/2011 tentang Pengesahan Konvensi mengenai Hak-Hak Penyandang Disabilitas (CRPD). Konvensi ini menjamin hak-hak penyandang disabillitas dalam berkehidupan berbangsa dan bernegara, termasuk juga hak-hak anak penyandang disabilitas yang berhadapan dengan hukum sebagai pelaku tindak pidana. UU 18/2014 tentang Kesehatan Jiwa yang memastikan bahwa bagi penyandang disabilitas dengan gangguan jiwa (ODGJ) yang diduga telah melakukan tindak pidana, wajib dilakukan pemeriksaan kesehatan jiwa terlebih dahulu oleh ahli yang bersangkutan seperti dokter spesialis kejiwaan untuk mengetahui kondisi kejiwaan seseorang dalam rangka kepentingan penegakkan hukum. UU 8/2016 tentang Penyandang Disabilitas secara spesifik menentukan bahwa anak penyandang disabilitas berhak mendapat pendampingan sosial yang bisa memahami kebutuhannya guna pemeriksaan dalam proses hukum. UU 11/2012 tentang Sistem Peradilan Pidana Anak diiatur bahwa dalam menangani kasus anak yang berkonflik dengan hukum, wajib diupayakan diversi dengan pendekatan keadilan restoratif. Selanjutnya terkait penerapan konsep diversi terhadap anak penyandang disabilitas pelaku tindak pidana kekerasan harus diupayakan pada setiap tahap proses hukum mulai dari tahap penyidikan, penuntutan, hingga peradilan di pengadilan serta penting bagi aparat penegak hukum untuk memahami prosedur dan hak-hak yang harus dipenuhi terhadap anak penyandang disabilitas berhadapan dengan hukum. Anak yang berkonflik dengan hukum sebisa mungkin dihindarkan dari hukuman penjara, karena pemenjaraan tidak baik bagi proses tumbuh kembang anak serta masa depan anak.

\section{DAFTAR PUSTAKA}

Adelina, Theresia, and A. A. Ngurah Yusa Darmadi. "Perlindungan Hukum Terhadap Anak Sebagai Pelaku Tindak Pidana Penganiayaan (Di Wilayah Hukum Kepolisian Resor Kota Denpasar)." Kertha Wicara: Journal Ilmu Hukum 7, no. 5 (2017): 1-15.

Anshar, Dio, Bestha Inatsan Ashila, Gita Nadia Pramesa, Nurul Saadah, and Ayatullah R. K. Disabilitas Berhadapan Dengan Hukum Dalam Lingkup 
Pengadilan. Edited by Theodora Y. S Putri and Muhammad Joni Yulianto. MaPPI FHUI \& AIPJ 2, 2019.

Anzward, Bruce, and Suko Widodo. "Kebijakan Penerapan Diversi Dalam Penyelesaian Perkara Tindak Pidana Yang Dilakukan Oleh Anak Melalui Pendekatan Restorative Justice." Jurnal De Facto 7, no. 1 (2020): 38-59.

Arianto, Henry. "Hak-Hak Bagi Para Penyandang Cacat (Disabilitas) Dalam Memperoleh Keadilan," 2017.

Benuf, Kornelius, and Muhamad Azhar. "Metodologi Penelitian Hukum Sebagai Instrumen Mengurai Permasalahan Hukum Kontemporer." Gema Keadilan 7, no. 1 (2020): 20-33. https://doi.org/10.14710/gk.7.1.20-33.

Eddyono, Supriyadi Widodo, and Ajeng Gandini Kamilah. Aspek - Aspek Criminal Justice Bagi Penyandang Disabilitas. Edited by Widiyanto. Institute for Criminal Justice Reform, 2015.

Gosita, Arif. "Masalah Perlindungan Anak," 28. Jakarta: Sinar Grafika, 1992.

Harefa, Beniharmoni. "Diversi Sebagai Perlindungan Hukum Terhadap Hak Asasi Anak Dalam Sistem Peradilan Pidana Anak Di Indonesia." Jurnal Komunikasi Hukum 1, no. 1 (2015): 1-13.

Indonesia, Republik. Kitab Undang-Undang Hukum Pidana (n.d.).

—. Undang-Undang Nomor 11 Tahun 2012 Tentang Sistem Peradilan Pidana Anak (2012).

_. Undang-Undang Nomor 18 Tahun 2014 Tentang Kesehatan Jiwa (2014).

. Undang-Undang Nomor 19 Tahun 2011 Tentang Pengesahan Convention on the Rights of Persons with Disabilities (Konvensi Mengenai Hak-Hak Penyandang Disabilitas) (2011).

- Undang-Undang Nomor 35 Tahun 2014 Tentang Perubahan Atas UndangUndang Nomor 23 Tahun 2002 Tentang Perlindungan Anak (2014).

_. Undang-Undang Nomor 39 Tahun 1999 Tentang Hak Asasi Manusia (1999).

_. Undang-Undang Nomor 8 Tahun 2016 Tentang Penyandang Disabilitas (2016).

Jones, Katherine Elisabeth, Shelly Ben-david, and Rachelle Hole. "Are Individuals with Intellectual and Developmental Disabilities Included in Research? A Review of the Literature." Research and Practice in Intellectual and Developmental Disabilities, 2019, 1-21. https://doi.org/10.1080/23297018.2019.1627571.

Judge, Zulfikar. "Kedudukan Anak Yang Berhadapan Dengan Hukum Selaku Pelaku Tindak Pidana (Studi Kasus : 123/PID.SUS/2014/PN.JKT.TIM).” Lex Jurnalica 13, no. 1 (2016).

Lampatta, Muhammad Rizal, and Irham Yasir. "Perlindungan Hukum Terhadap Tersangka Anak Dalam Proses Penyidikan Di Kepolisian Resor Pohuwato" 2, no. 1 (2020): 56-69.

Muryantini, Ni Nyoman, and I Komang Setia Buana. "Perlindungan Hukum Terhadap Anak Penyandang Disabilitas Yang Ditelantarkan Oleh Orang Tuanya.” Jurnal Advokasi 9, no. 1 (2019): 56-66.

Priamsari, R R Putri A. "Hukum Yang Berkeadilan Bagi Penyandang Disabilitas." Masalah-Masalah Hukum 48, no. 2 (2019): 215-23. 
Raharjo, Trisno, and Laras Astuti. "Konsep Diversi Terhadap Anak Penyandang Disabilitas Sebagai Pelaku Tindak Pidana Dalam Sistem Peradilan Pidana Anak" 24, no. 2 (2017): 181-92. https://doi.org/10.18196/jmh.2017.0094.181192.

Ratomi, Achmad. "Konsep Prosedur Pelaksanaan Diversi Pada Tahap Penyidikan Dalam Penyelesaian Tindak Pidana Yang Dilakukan Oleh Anak" 7 (n.d.): 394407.

Sihombing, Ricky Martin, M Hamdan, and Marlina. "Perlindungan Hukum Terhadap Anak Sebagai Pelaku Tindak Pidana Kekerasan (Analisis Putusan No. 9/PID.SUS-ANAK/2018/PN TJB)." Jurnal Mahupiki 1, no. 9 (2019).

Sodiqin, Ali. "Ambigiusitas Perlindungan Hukum Penyandang Disabilitas Dalam Perundang-Undangan Di Indonesia." Jurnal Legislasi Indonesia 18, no. 1 (2021): 31-44.

Suwandewi, Ni Ketut Ayu, and Ni Nengah Adiyaryani. "Diversi Sebagai Bentuk Perlindungan Anak Dalam Sistem Peradilan Di Indonesia." Kertha Patrika 42, no. 3 (2020): 275-87.

Tarigan, Fetri A. R. “Upaya Diversi Bagi Anak Dalam Proses Peradilan.” Lex Crimen IV, no. 5 (2015): 104-12.

Wahyudhi, Dheny, and Sri Rahayu. "Pemenuhan Hak-Hak Anak Yang Berkonflik Dengan Hukum Melalui Proses Diversi Dalam Peradilan Anak." In Prosiding Seminar Hukum Dan Publikasi Nasional (Serumpun), 72-94, 2019.

Waluyadi. "Hukum Perlindungan Anak," 1. Bandung: Mandar Maju, 2009.

Wulczyn, Fred, Arno Parolini, and Scott Huhr. "Human Capital and Child Protection: A Research Framework in the CRC Context." Child Abuse \& Neglect 119 (2021): 1-13. https://doi.org/10.1016/j.chiabu.2020.104610. 